The Geographical Journal of Nepal

Vol. 10: 1-14, 2017

Central Department of Geography,

Tribhuvan University, Kathmandu, Nepal

\title{
Are doomsday scenarios best seen as failed predictions or political detonators? The case of the 'Theory of Himalayan Environmental Degradation'
}

\author{
Tor H Aase \\ Department of Geography, University of Bergen, Bergen, Norway \\ Email: Tor.Aase@uib.no
}

The so-called 'Theory of Himalayan Environmental Degradation' predicted an environmental collapse by the end of last millennium, threatening the life of millions of people. Fortunately, the all-encompassing crisis did not materialize. The article shows that the 'Theory' failed to take into account the vast ecological variation in Himalaya and thus generalized its contentions to the whole mountain range on the basis of deficient data. But, on the other hand, what would have happened if the prediction had not been made? A doomsday scenario like the Theory of Himalayan Degradation can, from the perspective of positivist hypothesis testing, be viewed a posteriori as a failed prediction; but from another perspective it can be seen as an alarm clock that triggered a series of policy initiatives and new knowledge.

Keywords: Environmental degradation; Himalaya; farming systems; ecological variation

\section{Introduction}

From time to time, doomsday scenarios enter global academic and political discourses. The gloomy future that was intimated in The Limits to Growth created great havoc in the 1970s (Meadows et al., 1972). More recently, Huntington's notion of the Clash of Civilisations (1993) activated a heated debate over the future of multiculturalism. A hallmark of such scenarios is that they rarely come true. The 1984 passed much more pleasantly than Huxley envisaged. But should we thereby dismiss them as useless, as failed predictions that the world would have made better without? 
This article looks at one such prediction. The 'Theory of Himalayan Environmental Degradation' predicted an environmental collapse in the world's greatest mountains by the end of last millennium, threatening the life of millions of people. Fortunately, the all-encompassing crisis did not materialize. But what would have happened if the prediction had not been made? The article asks if doomsday scenarios like the Theory of Himalayan Degradation could be regarded as an alarm clock which sets academics and politicians in motion, rather than ridiculing them on hindsight as nothing more than failed predictions.

\section{The Theory of Himalayan environmental degradation}

On an international conference on Development of Mountain Environment in Munich 1975 several alarming observations were disseminated, creating a general feeling among the participants of a pending catastrophe in the world's mountain regions (Ives, 2006). Later the same year, Erik Eckholm published an article in the journal 'Science' that triggered a debate over the fate of Himalaya that has persisted to the present day (Eckholm, 1975). The article expressed grave concern that an environmental collapse would occur in the near future, affecting millions of people in the mountains as well as on the downstream plains.

Eckholm's argument ran thus: Assisted by international donor countries, improvements in medical- and veterinary services lowered the death rates of human and animal populations in the 1950 s without also lowering birth rates. Because the resulting population increase was not followed up by economic modernisation, perpetuation of the traditional agro-pastoral farming system came to exert intolerable pressure on the natural resource base. Ever more forest was cleared for cultivation and steep slopes were converted into terraced fields. By that, two negative spirals of environmental degradation started. Firstly, the torrential rains which are brought on by the monsoon caused sheet and gully erosion on deforested land and landslides on terraced slopes. Instead of being retained by forests, surface run-off brought rainwater directly to streams and rivers, thus causing flooding on the plains. The second spiral relates to energy. Since Himalayan households mainly rely on firewood for cooking and heating, the receding forests implied that animal dung came to be used for burning, like it is on the plains. Depriving the land of the previously applied manure lowered productivity; and because the per hectare productivity decreased, ever more areas came under the plough in order to feed a growing population, thus further depleting the forests.

This reasoning has later become known as "The Theory of Himalayan Environmental Degradation" (Ives \& Messerly, 1989). In short, it postulates that a 
growing population of agro-pastoral cultivators causes deforestation and serious land degradation in the mountains and flooding on the plains. The catastrophic floods in Bangladesh and on the Gangetic plain are, in other words, caused by the hill farmers.

Figure 1 below summarises the 'Theory of Himalayan Degradation'. The agropastoral farming system implies a combination of cultivation and animal husbandry. In the middle hills of Himalaya, staples like wheat, rice, potatoes and maize are cultivated on irrigated (khet) or rainfed (bari) terraced fields. Since cultivation implies the removal of nutrients from soils, artificial re-fertilization is necessary in order to maintain productivity. For that purpose a mixture of animal manure, litter from forests and crop residues are traditionally used. Thus, domesticated animals are not only an addition to cultivation but an integral part of the farming system as such. Human population increase is paralleled by an increased demand for staples, which in turn can only be met by more animals producing manure to be applied on a widening area of cultivated land. An increasing number of agro-pastoral households, then, lead to more land being cultivated and more land being transformed into pastures. The extension of farmland takes place at the expense of forests which are diminished. The ultimate consequences of this process are degradation in the mountains and flooding on the plains, which is the basic message in the 'Theory of Himalayan Environmental Degradation'.

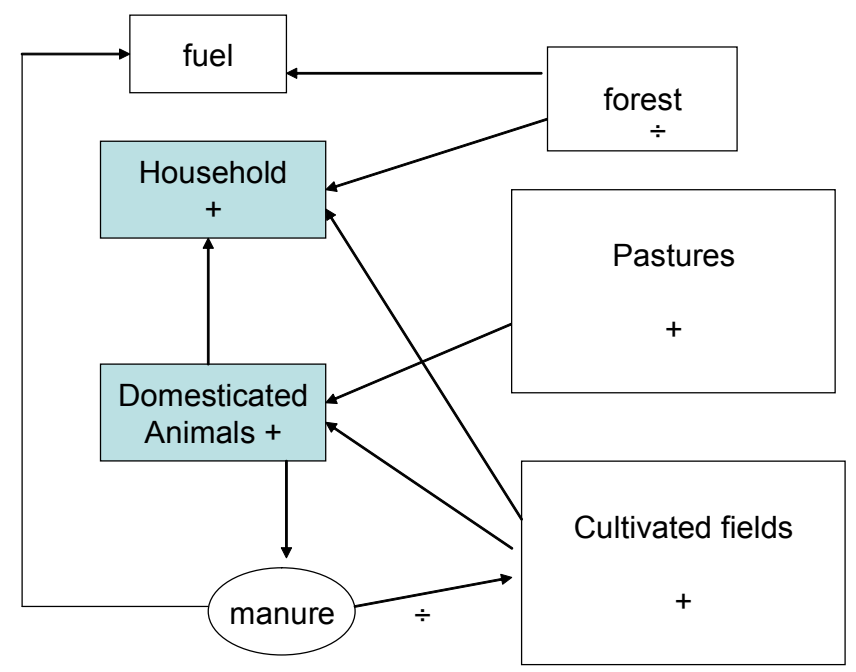

Figure 1. Population growth and deforestation in the Himalayas (after Eckholm 1975).

The 'Theory' soon became a hegemonic narrative throughout the community of mountain researchers and policy makers. The World Bank wrote 
"Nepal has lost half its forest cover within a thirty year period (1950-80) and by AD 2000 no accessible forests will remain" (World Bank, 1979).

In a similar vein, the Asian Development Bank mentioned that "(there is a) distinct danger that all accessible forests, especially in the hills, will be eliminated within less than 20 years" (ADB, 1982:12).

The World Resources Institute was clear in identifying the cause of the pending disaster "a few million subsistence hill farmers are undermining the life support of several hundred million people in the plains" (World Resources Institute 1985).

Jack Ives (2006), from whom these citations are taken, lists a number of doomsday predictions that emerged in research publications, in policy documents, and in the popular press during the fifteen years to follow the Munich conference. And the persuasive power of the 'Theory' has not only been limited to western writers. In 1981, a Nepali geologist published a book where the policy message was that "half of the hill population needs to be settled in the Terai (plains) and at the same time birth control should be considered seriously" (Sharma 1981:58). Sharma (1981) recommended that the remaining hill population should turn to horticulture in order to prevent further erosion.

The 'Theory' soon achieved wide credibility since "it was an intellectually satisfying concept, an environmental 'theory of everything', so plausible that it was widely accepted as a fact" (Ives, 2006:8). Furthermore, it was approved because it corresponded to the problem-solving capacity of international donors and national policy makers (Thompson \& Gyawali 2007:XIX).

Eckholm (1975) claimed that the Theory was valid throughout Nepal and Kashmir, but it proves that it was based on case studies carried out in the middle hills of central Nepal only. This way of generalising on the basis of a few case studies invites, of course, to criticism. Adherents to the epistemological position called 'post-development' claim that universalising, nomothetic theories ignore the complexity that makes up the whole and are thus not more than misrepresentations of reality (Tucker, 1999). And even worse, in our case, Ives claims that the 'Theory' was 'based on reports of 'experts', prepared in Kathmandu's best hotels, but preferably not during the summer monsoon, the peak season for landslides, leeches, and maximum discomfort for field travel" (Ives, 2006:234). Rather than aiming for 'grand narratives' that claim validity 
across time and space, post-development opts for local idiographic analyses of phenomena in their proper time-space context. And indeed, if we proceed from the middle hills of Nepal to the Pakistani part of Kashmir, a radically different picture emerges.

\section{More people produce more forests in Northern Pakistan}

Cultivators in the mountainous north of Pakistan practice the same kind of agropastoral farming system as the farmers Eckholm was writing about in Nepal. Wheat, maize, and vegetables are cultivated in the valley bottom and farmers keep cattle, sheep and goats for manure, milk and meat. But climate and environment are different from those in the middle hills of Nepal, and that fact produces quite opposite results of population growth.

The Gilgit-Baltistan Province of Pakistan is a semi-arid area. In the administrative headquarters of Gilgit annual precipitation is a mere $125 \mathrm{~mm}$. Valley bottoms are barren, the only vegetation being grasses and scattered brushes. But on high elevations, above 3500 meters, natural forests of Himalayan blue pine and birch thrive, succeeded by alpine meadows between 4000 and 5000 meters. The presence of high mountain forests above the dry valleys is produced by orographic conditions. When air becomes cooler due to increased elevation, moisture is condensed into mist and rain, and higher, into snow. In addition, evaporation is less on high altitudes.

Settlements are found in the main Indus valley and its numerous side valleys. Since the valleys are barren from nature, the vital task for farmers is to combine cultivable land (das) with water. Impressive canals of several kilometres are constructed in mountain sides to divert water from glacial streams to irrigate the das land. The problem of maintaining soil fertility is here, like in Nepal, solved by collecting animal manure and spreading it out on the land. Domesticated animals are vital for cultivation. A challenge for farmers, then, is to feed the animals.

In summer, animals are taken to the high alpine meadows where pastures are plentiful in a typical transhumant manner. The bottleneck in the farming system is to feed animals during winter when high pastures are covered in snow. At that time, animals mostly have to be stall-fed in the villages. They are given straw of cereals that are dried after harvest in the autumn and other agricultural 
residues. In addition, trees are lopped for foliage and used as fodder. Forests are thus essential units in the farming system.

People distinguish between two kinds of forests. The natural high mountain forest is called tom, and due to its high elevation it is inaccessible for daily use. People have traditionally brought timber for house construction from the high forest, but it is too remotely located for collecting firewood and foliage. The farming system hardly interacts with the high forest at all, human activity being limited to some modest logging and hunting for wild game.

The other forest is labelled bonni. Deciduous bonni forests are found around villages in the valley bottoms. But since the valleys are semi-arid, all bonni forests are artificially irrigated. It is the bonni forests that keep domesticated animals alive during winter. Various tree species with leaves of high nutritional value are deliberately planted and irrigated. There is a correlation between productivity on farmland, number of domesticated animals, and bonni forest. The more fields a farmer cultivates the more manure he needs, and the more bonni forest he must have access to in order to feed animals over the winter.

The corollary of agro-pastoral farming in the semi-arid Pakistan Himalaya is that population growth leads to increase of bonni forest cover. This is quite opposite to the situation described by the 'Theory', according to which population growth leads to deforestation. The Northern Areas of Pakistan have, like Nepal, seen a population growth lately. In Nepal, the 'Theory' contends that an increasing number of villagers are sustained by expanding the cultivated area on expense of forests that are becoming depleted. In northern Pakistan, quite contrary, the problem of supporting a growing population is solved by constructing ever longer canals from glacial streams to new das land, which is quite abundant in the area. And in order to practice the traditional agro-pastoral farming, bonni forest must be planted. In the semi-arid northern areas of Pakistan the formula is: more people - more forest!

The same kind of agro-pastoral farming has quite opposite effects on forests when it is practiced in different climate-ecological environments. In the wet middle hills of Nepal, extension of the active farming area encroaches on the forests. In semi-arid Gilgit, on the other hand, forests become more abundant when the cultivated area increases. 
It must be noted that deforestation is also a serious problem in Pakistan. But it is important to keep in mind the two kinds of forests in that area. Deforestation is only taking place in the natural high mountain forests and not in the irrigated valley bonni groves. The completion of the Karakorum Highway which passes through the Upper Indus Valley opened up previously inaccessible forests for logging in the 1980s. Especially in the Tribal Areas where the central government has limited authority, the high mountain forests of blue pine are decimated rapidly. Trees of 250 years or more of age which are highly valued by furniture makers in Pakistani cities are cut, transported on slides, sledges or tractors to the nearest road and sold to waiting contractors from the plains. Little replanting is done. But it is important to underline that this environmental tragedy has nothing to do with the agro-pastoral farming system. Rather, it must be related to the political system. The Tribal Areas of Pakistan are mostly acephalous, meaning that there is a lack of central political authority. In such a system, the primary social unit, the family, is in the last instance the architect of its own fortune. It has to defend its interests - most importantly land, water, and female reproductive capacity - against predatory neighbours by its own means. And for that, weapons are needed. The concomitant arms race between competing and frequently feuding families creates a next to insatiable demand for cash, which is obtained through logging. Remnants of the western Himalayan forests are, so to speak, converted into weapons (Aase, 2002).

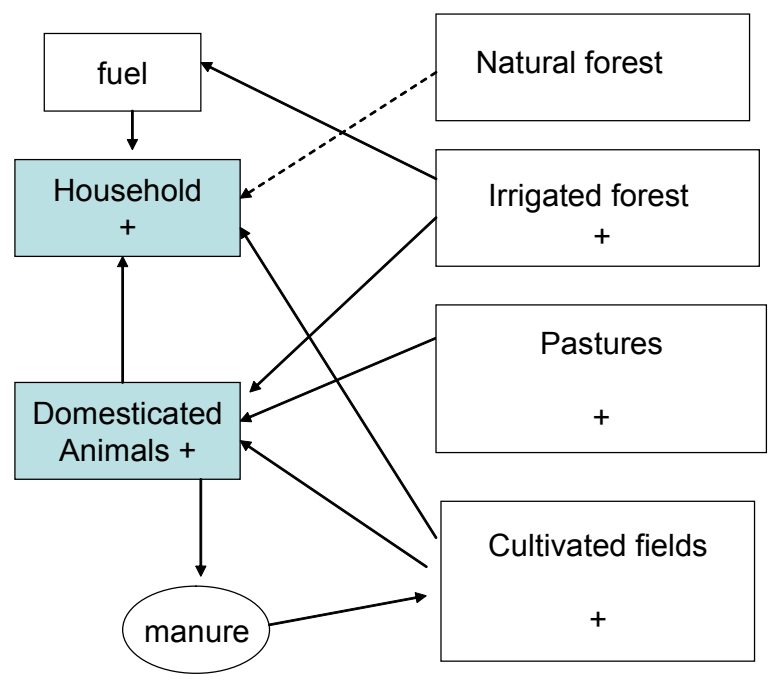

Figure 2. Population growth and forestation in Northern Areas of Pakistan (dashed line refers to minor flow). 
Tor H Aase / The Geographical Journal of Nepal Vol. 10: 1-14, 2017

The Pakistan case shows that the one and the same phenomenon, in this case deforestation, can be caused by radically different circumstances. Indeed, the vast complexity of man-nature interactions in the Himalayas was one of the grievances against the 'Theory' that started to be formulated ten years after it was introduced.

\section{Refuting the 'Theory'}

The pioneering opponents to the 'Theory' were Thompson, Warburton and Hatley who published Uncertainty on a Himalayan Scale in 1986. The book contends that the "Theory' (or "the orthodox definition" as they call it) violates the vast complexity of environments and human practices to be found in the region by claiming universal validity and by appointing the poor subsistence hill farmers to be the culprits behind the emerging tragedy. By applying their special version of 'cultural theory', Thompson et al., (1986) claim that the discourse on the Himalayan environment has been heavily biased in favour of one 'voice' - or one out of four possible stakeholder positions namely, the international donor position. The "environmental orthodoxy" "has provided the basis for decades worth of research and development aid in the whole region" (Thompson \& Gyawali 2007:xix).

A few years later, the opposition to the 'Theory' was strongly reinforced by Ives and Messerly (1989). Their book: The Himalayan Dilemma: Reconciling Development and Conservation (1989) thoroughly documents the variable state of Himalayan landscapes and communities. They do not deny that there are problems and challenges in the region, but maintain that "a supercrisis is not imminent and the scene is set rather for a deepening of a series of chronic problems" (Ives \& Messerly, 1989:237). The problems are not, however, created by the hill farmers; rather, they are combined outcomes of international border conflicts, failed mega-projects, mismanagement of aid funds, and a general lack of understanding of the situation of the poor.

Ives claims that the 'alarmist discourse' of the 1970s and 1980s was founded on misleading perceptions, misconceptions, and distortions (Ives, 2006:227). In the same vein, Thompson and Gyawali contend that "millions and millions of dollars' worth of aid has been directed at solving the wrong problems" (Thompson \& Gyawali 2007:xxiii). There is a salient gloating over the failure of the 'Theory' in their recent publication, since "Today Nepal's middle hills are better canopied than they have ever been since they were first settled" (ibid.:xvi). It is thus close at hand to write off the Theory as just 
another doomsday scenario that did not materialize. But there is an alternative way of perceiving it. What had happened if the Theory was not published thirty-five years ago? Would the forests have been as healthy as they prove to be today? This we cannot know, of course, but it is possible to regard the Theory as a kind of self-denying prophesy rather than a failed prediction.

\section{Was the Theory of Himalayan Degradation a flop or a timely warning?}

Most writers agree that the state of Himalayan forests was deteriorating during the $1950 \mathrm{~s}$ and 1960s, but the recent development is less clear. The former Director of the International Centre of Integrated Mountain Development (ICIMOD) agrees with Thompson and Gyawali when he maintains that "community forestry has reversed deforestation trends in Nepal" (Campbell, 2008:25). On the other hand, forest cover in Nepalis reported to have decreased by $1.0 \%$ annually during the $1980 \mathrm{~s}$ while the annual loss was 1.1\% during 1991-1995 (Kaosa-ard \& Rerkasem, 2000). Jack Ives, after scrutinising various parts of the Himalayas, offers a more varied conclusion: "some areas of this vast and complex mountain region have been ruthlessly stripped off most forest cover while other areas still have well maintained forests, or have even been reforested to various degrees" (Ives, 2006:79). At least, time has thoroughly refuted the gloomy predictions of the Theory.

The positive turn of forest development during the last twenty years is ascribed to community forestry by most writers on the topic. Ives, for example, writes that "between 1978 and 1992 community forestry activities at lower altitudes have had beneficial impacts on the local forests and the overall stability of the land-use system" (Ives, 2006:50); and Thompson and Gyawali (2007) claim that Nepal's healthy canopy is thanks to efforts of Community Forestry that began in the mid-1980s.

The leading voices on the counter-narrative side, Thompson et al. (1986) and Ives and Messerly (1989), leave no doubt that the 'Theory' was wrong. The saviour of Himalayan forests emerged to be Community Forestry organised according to the principle of local participation. But it may well be that it was exactly the Theory, inspiring the 'alarmist discourse', that paved the way for Community Forestry. Looking at things from that perspective, the Theory was an eye-opener that set policy-making in motion. The Theory was the hare, to speak metaphorically, in the race against deforestation and massive land degradation in the Himalayas. 


\section{The new orthodoxy: Local participation}

Nepal can now boast 20,000 community Forest User Groups (FUG) who manage a total of 1.2 million hectares of forest (Campbell, 2008). The FUGs are headed by a committee in which all castes and all genders must be represented. FUGs implement and to a certain extent make rules for local use of forest resources, and extract taxes from the users. The taxes are used for community projects like building of bridges, maintenance of village roads and irrigation canals. The FUGs report to the State via the Forest Ranger, whose task is to watch the community activities that are carried out within the limits set by the Government.

The introduction of FUG is a success story in Nepal; indeed, it is one of the few development initiatives that Nepal can proudly show to the outside world. But the institution has its flaws. Critiques claim that FUGs may care for the forest in an excellent manner, but their success is more modest when it comes to poverty alleviation which is another stated objective of the institution. Poor low caste people are the ones who occasionally must harvest forest resources illegally in order to survive, and for that they are often expelled from the FUG, loosing whatever rights they might have had to the forest. In that manner, the FUGs reproduce and even reinforce village power structures.

Because influential villagers are usually endowed with substantial social capital, it is sometimes tempting to convert that capital into material gains by undertaking various kinds of transactions with the forest officials. In India, Saxena contends that "The best friends of the Forest Department are the village elite who dominate the Joint Forest Management Committees" (Saxena, 2008:45). Powerful members of the Community Forest Committees (CFC, corresponding to the Nepali FUG) manage to enrich themselves in various inventive ways, for which Saxena prefers to label their activity committee forestry rather than community forestry.

A third problem relates to local monopoly of forest resources. In the Nepali valley of Mustang, the FUGs allow the original settlers to collect fungi, fodder, and other forest resources two days before the new settlers are allowed into the forest, thus reserving the best pieces close to the settlements for the 'authentic' villagers.

Adherents of Community Forestry are aware of these problems. But the advantages allegedly outweigh the shortcomings. The defects of FUGs are categorized || $10 \|$ 
as 'second generation issues' and should be addressed now when the principle of local participation has gained momentum (Sharma et al., 2008). It is correct to argue, then, that the trust in local participation has become the new paradigm in environmental policy making. It is not least so in the Himalayas, where Sharma contends that "The notion that "conservation and management of natural resources are impossible without people's participation" is now becoming the guiding principle of community-based biodiversity management" (Sharma et al., 2008:84). 'Local participation' has become the new mantra of development.

History sometimes repeats itself. The discourse on local participation now holds an uncontested position much like the 'alarmist discourse' did during the 15 years to follow the publication of the Theory of Himalayan Degradation. And criticism runs off the new discourse like water on a duck's back. Sumitra Manandhar Gurung, an experienced Nepali NGO worker, puts it this way: "But anyone who dares to question (the success of FUGs) will tear away the national pride around an established "successful case" from Nepal, a model worthy of being exported elsewhere” (Gurung, 2007:249).

What is the origin of the belief in local participation? FUGs in Nepal and CFCs in India neatly fit into the present global ideology claiming that social capital, democracy, accountability, and good governance are necessary steps on the path to sustainable development. These ideas have travelled from the same institutions which embraced the Theory of Himalayan Degradation thirty years ago, to eventually reach recipient countries in need for development (whatever that may be). "Since globalization is not taking place in Nepal through trade or investment, only Indianization, it is the aid regime that has largely been the main harbinger of globalization" (Subba \& Upreti, 1998:136). The World Bank, UNDP, international NGOs and overseas development agencies are the vehicles on which the new ideas have travelled to Nepal, like they were also carriers of the'Theory' thirty years ago.

Once the hegemonic voice has had time to speak for some time, its message tends to be internalized by the audience. Gurung noticed that the global discourse has been engraved in the national Nepali discourse on development and environment: "Now after twenty years in the "development game", I have come to realize that the mythmakers of today are no longer foreign experts, but the new Nepali elites, academics, consultants and the government" (Gurung, 2007:253). 
Tor H Aase / The Geographical Journal of Nepal Vol. 10: 1-14, 2017

I shall not speculate over the origin of global development discourses. Thompson et al. (1986) relate ideologies to the stakeholder positions of powerful global actors like UN and WB who favour problem-identifications that match their available solutions, while Ives is inclined to blame quasi-research and hasty generalisations for narratives of dubious nature that are sometimes canonised into 'facts'. Suffice it here to confirm that global discourses, or, more accurate, perspectives on sustainable development insisted upon by powerful global actors, tend to be internalized by national and local actors in recipient countries and converted into practical policies. That happened with the alarmist discourse, which, according to Thompson and Gyawali, channelized billions of dollars into certain kinds of development projects; and it happens now with national pride in community forestry based on the fashionable paradigm of local participation. But that may not be an ugly fashion! Like the 'Theory' probably mobilised academics as well as policy makers thirty years ago, the present emphasis on local participation implies the triple ambition of alleviating poverty, empowering the weak, and saving the environment. In the last instance, this intriguing ambition can trace its trajectory back to the Munich conference in 1975 when the Theory was introduced. A doomsday scenario like the Theory of Himalayan Degradation can, from the perspective of positivist hypothesis testing, be viewed a posteriori as a failed prediction; but from another perspective it can be seen as an alarm clock that triggered a series of policy initiatives and new knowledge.

\section{References}

Aase, T.H.(Ed).(2002). Tournaments ofpower: Honour and revenge in the Contemporary world. Aldershot: Ashgate Publications

ADB. (1982). Nepal agricultural sector strategy study, $2^{\text {nd }}$ vol; Kathmandu: Asian Development Bank

Campbell, J.G. (2008). Sustainable mountain development: Reflections on supporting the development of inclusive and pro-environment policies in the Himalaya. In Rasul, G. and Karki, M. (Eds). Policy priorities for sustainable mountain development. Kathmandu: ICIMOD

Eckholm, E. (1975). The deterioration of mountain environments. Science 189:764-70 
Tor H Aase / The Geographical Journal of Nepal Vol. 10: 1-14, 2017

Gurung, S. M. (2007). Beyond the myth of eco-crisis: Local responses to pressure on land in Nepal. Kathmandu: Mandala Publications

Huntington, S. (1993). The clash of civilisations. New York: Simeon \& Schuster

Ives, J., \& Messerli, B. (1989). Himalayan dilemma: Reconciling development and conservation. London: Routledge

Ives, J. (2006). Himalayan perceptions: Environmental change and the well-being of mountain peoples. Abingdon: Routledge

Kaosa-ard, M.S., \& Rerkasem, B. (2000). The growth and sustainability of agriculture in Asia. Hong Kong: Oxford University Press (China)

Meadows, D.H., Meadows, D.L., Randers, J., \& Behrens, W.W. (1972). The Limits to growth. White River Junction, VT US: Chelsea Green Publishers

Saxena, N. C. (2008). Policy issues for sustainable natural resource management in the Indian Himalayas: Participation, decentralisation, and regional cooperation. In Rasul, G. and Karki, M. (Eds): Policy Priorities for Sustainable Mountain Development. Kathmandu: ICIMOD

Sharma, C. K. (1981). Landslides and Soil Erosion in Nepal. Kathmandu: Sangeeta Sharma

Sharma, E., Chettri, N., \& Shakya, B. (2008). Lessons and prospects for increased regional cooperation in the conservation of biological diversity and cultural heritage: An overview of the Hindu Kush - Himalaya. In Rasul, G. and Karki, M.(Eds). Policy Priorities for Sustainable Mountain Development. Kathmandu: ICIMOD

Subba, P., \& Upreti, H. (1998). Impact of globalization: How to resolve the Nepalese security dilemma. In Dahal, M.K. (ed). Impact of Globalization in Nepal. Kathmandu: Nepal Foundation for Advanced Studies

Thompson, M., Warburton, M., \& Hatley, T. (1986). Uncertainty on a Himalayan scale. London: Ethnographia

Thompson, M., \& Gyawali, D. (2007). Introduction to the revised 2007 edition of Thompson, M., Warburton, M., \& Hatley, T. 1986: Uncertainty on a Himalayan Scale. London: Ethnographia 
Tor H Aase / The Geographical Journal of Nepal Vol. 10: 1-14, 2017

Tucker, V. (1999). The myth of development: A critique of a eurocentric discourse. In Munck, R. and O’Hearn D. (Eds). (1999). Critical Development Theory. London: Zed Books

World Bank. (1979). Nepal: Development performance and prospects. A World Bank Country Study, South Asia Regional Office, Washington D.C.

World Resources Institute. (1985). Tropical forests: A call to action. Washington D.C., WRI. 